Creative Commons User License: CC BY-NC-ND

Abstracted by: EBSCOhost, Electronic Journals Service (EJS)

Google Scholar, Journal Seek, Scientific Commons,

Food and Agricultural Organization (FAO), CABI and Scopus
Journal of Agricultural Extension

Vol. 23 (1) January, 2019

ISSN(e): 24086851; ISSN(Print); 1119944X

http://journal.aesonnigeria.org

http://www.ajol.info/index.php/iae

Email: editorinchief@aesonnigeria.org

\title{
Bridging Male-Female Gaps in Rural Entrepreneurship Capability Development in Osun State, Nigeria
}

https://dx.doi.org/10.4314/jae.v23i1.7

\author{
Alabi, Dorcas L. \\ Department of Agricultural Extension and Rural Development, Faculty of Agriculture, \\ Obafemi Awolowo University, Ile-Ife. Nigeria. \\ alabidorcas@yahoo.com +2348062915547
}

\author{
Famakinwa, Michael \\ Department of Agricultural Extension and Rural Development, Faculty of Agriculture, \\ Obafemi Awolowo University, Ile-Ife. Nigeria. \\ famakinwamichael2013@gmail.com +2347039530266
}

\section{Abstract}

The study described the socio-economic characteristics of male and female rural entrepreneurs in Osun state, Nigeria, identified the enterprise characteristics on gender basis, examined the causes of entrepreneurship gap and suggested the strategies to bridging the gap with the view to enhancing rural entrepreneurship capability development. Multistage sampling procedure was employed to select 150 respondents for the study from four local government areas of the state. Data were described with percentages, means and standard deviation while independent t test was used for inferential purpose. Results showed that the mean ages of male and female entrepreneurs were $42.6 \pm 8.6$ years and $42.3 \pm 12.1$ years, respectively and the majority (76\% and $81.3 \%$ ) of male and female respondents were married with the mean year of education of $13.4 \pm 3.7$ and $10 \pm 4.2$ years, respectively. Gaps were identified in the enterprise characteristics of respondents such as business choice with $30.7 \%$ and $40 \%$ of males and females, respectively engaging in agribusiness and trading: with average staff strength at 3 and 1 person(s), mean capital investment at $\mathbb{N} 26,326$ and $\mathrm{N}$ 14,013, mean income size at $\mathrm{N}$ 97,602 and $\mathrm{N}$ 35,698 and rate of exit at $59 \%$ and $53 \%$. There was a significant difference in male and female entrepreneurs' motives ( $t=-2.616 ; p \leq 0.01)$, perception ( $t=2.918 ; p \leq 0.05$ ), access to finance $(t=3.921 ; p \leq 0.01)$, among others. The significant variables were responsible for the observed male-female gap and adequate extension education on rural entrepreneurship capability development is germane to providing necessary enlightenment capable of minimizing gender differences among the rural entrepreneurs.

Key words: entrepreneurship, rural, bridge 
Creative Commons User License: CC BY-NC-ND

Abstracted by: EBSCOhost, Electronic Journals Service (EJS)

Google Scholar, Journal Seek, Scientific Commons,

Food and Agricultural Organization (FAO), CABI and Scopus

http://eoi.citefactor.org/10.11226/v23i1
Journal of Agricultural Extension

Vol. 23 (1) January, 2019

ISSN(e): 24086851; ISSN(Print); 1119944X

http://journal.aesonnigeria.org

http://www.ajol.info/index.php/jae

Email: editorinchief@aesonnigeria.org

\section{Introduction}

Deji (2012) asserted that there are socially created roles, norms, behaviour, expectations and activities attributed to women and men. Entrepreneurship is a process of identifying profitable opportunities from the environment, exploiting such opportunities by starting a relevant enterprise, carefully handling the risks and uncertainties involved and managing the enterprise operations in such a way that the set objectives would be attained (Robbins and Coulter, 1998). Gender equality has been identified as one of the eight Millennium Development Goals and a key to achieving the other seven goals (United Nations Population Fund, 2013). In the recent time, gender equality and female entrepreneurship have been identified as the key factors in economic development (Sarfaraz et al., 2014). There is also the consensus among scholars that women can play key roles in the entrepreneurial phenomenon and that gender inequality exists in terms of economic development as well as the rates of entrepreneurial activities. For instance, Allen et al. (2008) report significant gender gap in the entrepreneurial activities' rate across the world. Also, a Global Entrepreneurship Monitor (GEM) study of 18 countries from 2002 to 2010 suggest that women's entrepreneurial activity is lower than that of their male counterparts at different stages of development (Kelley et al., 2011).

Revenga and Sudhir (2012) reiterate that despite the fact that women constitute about half of the world population compared to men, they have lesser opportunities and consequently lesser entrepreneurial capability. They observe further that, though many international organizations including the United Nations and the World Bank have made several attempts to bridge the gender gap in access to opportunities, gender inequalities are still very rampant resulting in deprivation of women from having equal rights with men counterpart. Gender gap in entrepreneurship refers to the differences between men and women in terms of numbers engaging in entrepreneurial activities, choice of enterprise, and motives for starting the business as well as their business performance and growth, among others (Deepak et al., 2014).

Naude and Minnti (2011) observe significant differences in entrepreneurial behaviour across gender worldwide and report that fewer women than men own and manage businesses with women failing more often than men. This phenomenon, they observe, could be related to the different socio-economic characteristics of women and men such as level of education, wealth status, family background and work status. They observe further that the propensity of women to start a business may differ from that of men and that the businesses owned and managed by men and women are different. Deepak et al. (2014) added that women are mostly engaged in retail businesses and virtually absent from manufacturing and construction; their businesses tend to be smaller, grow lesser, less profitable, generate lower sales turnover and more likely to fail than those owned by men.

Rural entrepreneurship is that which evolves at village level and cuts across different fields of endeavour including agriculture, trade and industry and a type of entrepreneurship that ensures value addition to resources in rural areas (Nitin et al., 2011; Trupti, 2010). It has been identified as a strong factor for rural economic development (Nitin et al., 2011). Rural entrepreneurs are the energetic and self-motivated individuals or group of people who start a business within or outside agriculture or expand the existing business with full knowledge 
Creative Commons User License: CC BY-NC-ND

Abstracted by: EBSCOhost, Electronic Journals Service (EJS)

Google Scholar, Journal Seek, Scientific Commons,

Food and Agricultural Organization (FAO), CABI and Scopus
Journal of Agricultural Extension

Vol. 23 (1) January, 2019

ISSN(e): 24086851; ISSN(Print); 1119944X

http://journal.aesonnigeria.org

http://www.ajol.info/index.php/jae

Email: editorinchief@aesonnigeria.org

of risks involved (Sameer, 2014). Although, it has been established in literature that entrepreneurship gap exists between male and female globally (Kelley et al., 2011; Revenga and Sudhir 2012 and Naude and Minnti 2011) but the form it takes and the means to bridging the gap has not been adequately investigated in the study area, hence, the need for this study.

\section{Objectives of the Study}

The specific objectives were to:

- describe the socio-economic characteristics of male and female entrepreneurs in the study area;

- identify the enterprise characteristics based on sex;

- examine the causes of entrepreneurship gap; and

- identify the strategies of bridging the gap.

\section{Hypotheses}

- There is no significant difference between male and female enterprise characteristics.

- There is no significant difference in the causes of entrepreneurship gap between male and female entrepreneurs.

\section{Methodology}

The study was carried in the six administrative zones of Osun state, Nigeria. A multistage sampling procedure was used to select respondents. In the $1^{\text {st }}$ stage, three (i.e.50\%) of the six administrative zones were randomly selected, namely, Ife, Ede and Ilesa zones. In the $2^{\text {nd }}$ stage, one rural local government area (LGA) was randomly selected from each zone, namely, Ife North, Egbedore, and Atakumosa West LGAs from Ife, Ede and llesa zones, respectively. In the $3^{\text {rd }}$ stage, 23 percent of the rural communities in each of the selected LGAs were randomly chosen translating into two, five and seven communities from Egbedore, Atakumosa West and Ife North LGAs, respectively. At the last stage, 10 respondents (5 males and 5 females) were randomly selected from each community making a total of 150 respondents in all.

Enterprise characteristics was measured by using six indicators, namely: business choice, staff strength, initial capital outlay, average monthly income, exit rate and operational coverage. Business choice was measured by asking the respondents to indicate the type of enterprise they engaged in. Staff strength was measured by asking them to indicate the number of people working for them in their businesses and recorded as given. Respondents were asked to indicate their initial capital in naira and recorded as given. Average monthly income was measured by asking them to indicate the amount of money they realised from their enterprise monthly. They were also asked to indicate whether their businesses have ever folded up or not and if Yes, the number of times it had occurred. Operational coverage was measured by asking them to indicate the category of people who patronize their products most and scored accordingly: people in their household (1), people in their local community (2), people in their LGA (3), people in their state (4), people outside their state (5) and people outside the country (6). Furthermore, causes of entrepreneurship gap were measured by investigating respondents' business motive, 
Creative Commons User License: CC BY-NC-ND

Abstracted by: EBSCOhost, Electronic Journals Service (EJS)

Google Scholar, Journal Seek, Scientific Commons,

Food and Agricultural Organization (FAO), CABI and Scopus
Journal of Agricultural Extension

Vol. 23 (1) January, 2019

ISSN(e): 24086851; ISSN(Print); 1119944X

http://journal.aesonnigeria.org

http://www.ajol.info/index.php/iae

Email: editorinchief@aesonnigeria.org

behaviour and access to financial resources. Motive in business was measured by asking them to indicate the reasons for engaging in their enterprises and each identified reason was scored one point, while access to financial resources was measured by asking them to indicate whether they had access to formal sources of capital to finance their enterprise or not. Yes, was scored one point while no was scored zero point. Perception of the respondents toward entrepreneurship was measured by asking them to respond to eight perception statements and their responses were rated on a five point Likert scale ranging from strongly agreed (5 points), agreed (4 points). (3 points) undecided, disagreed (2 points) and strongly disagreed (1 point) for positive statements and vice-versa for negative statements. Strategies for bridging entrepreneurship gap were measured by asking the respondents to identify the means of closing the gap and each identified strategy was scored one point.

Data collected were analysed using frequency counts, percentages, means and standard deviation while independent $t$ test was used to draw inference. Objectives one to four were analysed with percentages, means and standard deviations while the hypotheses were tested using independent t test. Structured interview schedule was used to collect the data from the respondents on socio-economic characteristics such as age, sex and years of education; enterprise characteristics such as business choice, staff strength, operational coverage and causes of entrepreneurship gap such as business motive and behaviour; perception of male and female respondents towards entrepreneurship and strategies of bridging the gap.

\section{Results and Discussions}

\section{Socio-economic Characteristics}

Table 1 shows that the majority (96\% and $65 \%$ ) of male and female respondents, respectively were within the age bracket of 31-60 years while the mean ages were 42.6 \pm 8.6 years and $42.3 \pm 12.1$ years, respectively, implying maturity and active age that could enhance good entrepreneurial performance. The majority (76\% and $81.3 \%$ ) of male and female respondents, respectively were married. Marriage implies responsibilities that could necessitate diversification of economic activities. The finding agrees with the report of Fielden et al., (2000), which establishes a positive relationship between marital status and business performance. The mean years of formal education of male and female respondents were $13.4 \pm 3$.7and $10 \pm 4.2$ years, respectively. This result indicates that both gender had moderate level of education, implying that they stand better chances of accessing information that could enhance better business performance. More than half $(58.7 \%$ and $53.3 \%)$ of male and female respondents were indigenes of their various communities while the mean years of residence of male and female entrepreneurs were $21.8 \pm 10.3$ years and $23.3 \pm 14.2$ years, respectively. This shows that respondents have been living in the study area for a very long period of time which could enhance their accessibility to locally available resources. Also, the majority (92\% and $96 \%$ ) of male and female respondents had travelled outside their communities. This implies that they had high level of external orientation and exposure that could enhance their enlightenment. The finding is in line with Tunde and Adeniyi (2012) who opine that high level of cosmopoliteness leads to increase in non-farm enterprises. The years of experience in entrepreneurial activities of males and females were $6.7 \pm 2.4$ years and $5.3 \pm 1.9$ years 
Creative Commons User License: CC BY-NC-ND

Abstracted by: EBSCOhost, Electronic Journals Service (EJS)

Google Scholar, Journal Seek, Scientific Commons,

Food and Agricultural Organization (FAO), CABI and Scopus
Journal of Agricultural Extension

Vol. 23 (1) January, 2019

ISSN(e): 24086851; ISSN(Print); 1119944X

http://journal.aesonnigeria.org

http://www.ajol.info/index.php/iae

Email: editorinchief@aesonnigeria.org

respectively. This shows that respondents were still relatively new in their various enterprises and this is similar to the findings of Alabi et al., (2017) which reported that the mean years of experience of male and female involved in rural household based enterprises were 6.3years and 4.7 years respectively.

Table1: Distribution of respondents by their personal and socio-economic characteristics

\begin{tabular}{|c|c|c|}
\hline Socio-economic characteristics & $\begin{array}{l}\text { Male }(n=75) \\
\text { percentage }\end{array}$ & $\begin{array}{l}\text { Female }(\mathrm{n}=75) \\
\text { Percentage }\end{array}$ \\
\hline \multicolumn{3}{|l|}{ Age (in years) } \\
\hline$<30.00$ & 4.0 & 24.0 \\
\hline $30.00-60.00$ & 96.0 & 65.3 \\
\hline Above 60 & - & 10.7 \\
\hline Mean \pm Standard deviation & $42.6 \pm 8.6$ & $42.3 \pm 12.1$ \\
\hline \multicolumn{3}{|l|}{ Marital status } \\
\hline Single & 24.0 & 9.3 \\
\hline Married & 76.0 & 81.3 \\
\hline Divorce & - & 9.4 \\
\hline \multicolumn{3}{|l|}{ Years of education } \\
\hline$\leq 6.00$ & 12.0 & 16.0 \\
\hline $7.00-12.00$ & 21.3 & 57.3 \\
\hline$>13.00$ & 66.7 & 26.7 \\
\hline Mean \pm Standard deviation & $13.4 \pm 3.7$ & $10.4 \pm 4.6$ \\
\hline \multicolumn{3}{|l|}{ Indigenes } \\
\hline Non indigene & 41.3 & 46.7 \\
\hline Indigenes & 58.7 & 53.3 \\
\hline \multicolumn{3}{|l|}{ External orientation } \\
\hline Travelled within communities & 8.0 & 5.3 \\
\hline Outside local government & 9.3 & 12.0 \\
\hline Outside state & 61.4 & 68.0 \\
\hline Outside country & 21.3 & 14.7 \\
\hline \multicolumn{3}{|l|}{ Years of residence } \\
\hline$<10.00$ & 8.0 & 21.3 \\
\hline $10.00-29.00$ & 61.3 & 48.0 \\
\hline $30.00-50.00$ & 30.6 & 30.8 \\
\hline Mean \pm Standard deviation & $21.8 \pm 10.3$ & $23.3 \pm 14.2$ \\
\hline \multicolumn{3}{|l|}{ Years of experience } \\
\hline$<10.00$ & 30.7 & 62.7 \\
\hline $10.00-19.00$ & 56.0 & 16.0 \\
\hline $20.00+$ & 13.3 & 21.3 \\
\hline Mean \pm Standard deviation & $6.7 \pm 2.4$ & $5.3 \pm 1.9$ \\
\hline
\end{tabular}

Source: Field Survey, 2017

\section{Forms of Enterprise Characteristics}

Results in Table 2 show that respondents of both genders had multiple enterprise choices with crop production (65.0\%), marketing of agricultural products $(60.0 \%)$ and general merchandise (46.0\%) prevailing among males, while processing (66.7\%), value addition to crops $(55.5 \%)$ and marketing of agricultural products $(54.7 \%)$ were prominent among females. The implication is that males' and females' choice of enterprise differ. The result agrees with Naude and Minnti (2011) who observed that the businesses owned and managed by men and women are different. The mean staff strength of male and female respondents was 2 and 1 person(s), respectively. This implies that males' enterprise size 
Creative Commons User License: CC BY-NC-ND

Abstracted by: EBSCOhost, Electronic Journals Service (EJS) Google Scholar, Journal Seek, Scientific Commons,

Food and Agricultural Organization (FAO), CABI and Scopus
Journal of Agricultural Extension

Vol. 23 (1) January, 2019

ISSN(e): 24086851; ISSN(Print); 1119944X

http://journal.aesonnigeria.org

http://www.ajol.info/index.php/jae

Email: editorinchief@aesonnigeria.org

was relatively bigger than females and in agreement with Naude and Minnti (2011) who observe that women's businesses tend to be smaller than those of men. Further results show that the mean startup capital investment of male and female respondents were $\mathrm{A}$ $26,326 \pm$ 2,338 and $A 14,013 \pm 1062$, respectively, showing that investment of male entrepreneurs was almost double that of females. The mean monthly incomes realized by male and female respondents from their enterprises were $97602 \pm N 3338$ and 35698 \pm 3874 , respectively. This shows that males' income was much higher than females' in agreement with Naude and Minnti (2011) who posited that female businesses tend to be less profitable and generate lower sales turnover than those of males. This observation could be an indication that male enterprises were better managed and thriving better than females. However, comparison of the mean startup capitals of each gender with their mean incomes shows that there was noticeable growth in their enterprises. Above half (59\% and $53 \%$ ) of male and female respondents had never exited from their business. This is contrary to the belief that women do change their businesses from time to time. About half of male $(48.0 \%)$ and female $(50.7 \%)$ respondents indicated that their business operations were limited to the state and their local communities, respectively. This shows that males had wider operational coverage than females who mainly satisfied their neighbourhood. 
Creative Commons User License: CC BY-NC-ND

Abstracted by: EBSCOhost, Electronic Journals Se

Google Scholar, Journal Seek, Scientific Commons,

Food and Agricultural Organization (FAO), CABI and Scopus

http://eoi.citefactor.org/10.11226/v23i1

Table 2: Distribution of respondents by enterprise characteristics

\begin{tabular}{|c|c|c|}
\hline $\begin{array}{l}\text { Enterprise Characteristics } \\
\text { Indicators }\end{array}$ & $\begin{array}{l}\text { Male }(n=75) \\
\text { Percentage }\end{array}$ & $\begin{array}{l}\text { Female( }(n=75) \\
\text { Percentage }\end{array}$ \\
\hline \multicolumn{3}{|l|}{ Business choice } \\
\hline General merchandise & 46.0 & 24.2 \\
\hline Crop production & 65.0 & 20.4 \\
\hline Animal production & 32.0 & 28.1 \\
\hline Fish production & 13.3 & 10.7 \\
\hline Processing & 10.3 & 66.7 \\
\hline Value addition & 26.7 & 55.5 \\
\hline Marketing of agric. Products & 60.0 & 54.7 \\
\hline Sales of agro- inputs & 17.3 & 24 \\
\hline Hair dressing/barbing & 2.6 & 6.7 \\
\hline Tailoring & 16.5 & 29.3 \\
\hline \multicolumn{3}{|l|}{ Staff strength } \\
\hline No staff & 32.0 & 72.0 \\
\hline $1-3$ & 34.7 & 14.7 \\
\hline $3-6$ & 33.3 & 13.3 \\
\hline Mean \pm standard & $2.29 \pm 0.45$ & $08 \pm 0.33$ \\
\hline \multicolumn{3}{|l|}{ Initial capital outlay } \\
\hline$\leq \mathbb{N} 25000.00$ & 33.3 & 56.0 \\
\hline N $25001.00-N 75000.00$ & 30.7 & 20.0 \\
\hline N $75001.00-N 125000.00$ & 5.3 & 24.0 \\
\hline A $125001.00_{+}$ & 30.7 & \\
\hline Mean \pm standard deviation & A $26326 \pm$ N 2338 & A $14013 \pm$ N 1062 \\
\hline \multicolumn{3}{|l|}{ Average monthly income } \\
\hline$<N 50000.00$ & 81.3 & 93.3 \\
\hline A $50000.00-A 99999.00$ & 17.3 & 6.7 \\
\hline A $150000.00_{+}$ & 1.3 & - \\
\hline Mean standard deviation & N $97602 \pm N 3338$ & N $35698 \pm 3874$ \\
\hline \multicolumn{3}{|l|}{ Exit rate } \\
\hline Never & 78.7 & 70.7 \\
\hline 1 time & 9.3 & 29.3 \\
\hline 2 time & 12.0 & - \\
\hline \multicolumn{3}{|l|}{ Operational coverage } \\
\hline Household consumption only & 13.3 & 21.3 \\
\hline Local community & 14.7 & 50.7 \\
\hline Whole LGA & 16.0 & 14.7 \\
\hline For state & 48.0 & 13.3 \\
\hline For outside state & 8.0 & - \\
\hline
\end{tabular}

Journal of Agricultural Extension

Vol. 23 (1) January, 2019

ISSN(e): 24086851; ISSN(Print); 1119944X

http://journal.aesonnigeria.org

http://www.ajol.info/index.php/iae

Email: editorinchief@aesonnigeria.org

Source: Field Survey, 2017 
Creative Commons User License: CC BY-NC-ND

Abstracted by: EBSCOhost, Electronic Journals Service (EJS)

Google Scholar, Journal Seek, Scientific Commons,

Food and Agricultural Organization (FAO), CABI and Scopus
Journal of Agricultural Extension

Vol. 23 (1) January, 2019

ISSN(e): 24086851; ISSN(Print); 1119944X

http://journal.aesonnigeria.org

http://www.ajol.info/index.php/iae

Email: editorinchief@aesonnigeria.org

http://eoi.citefactor.org/10.11226/v23i1

\section{Causes of Entrepreneurship Gender Gap}

Results in Tables 3 and 4 show that entrepreneurship gender gap occurred as a result of differences in male and female entrepreneurs' motive, business behaviour, accessibility to financial resources and perception towards entrepreneurship. Table 3 shows that aside from profit making which was the common motive identified by the majority of male $(73.3 \%)$ and female $(65.5 \%)$ entrepreneurs, desire to contribute to community development $(30.7 \%)$ was the next important motive identified by males while augmenting family income $(65.3 \%)$ was the next important motive identified by female implying difference in motive. The finding is in line with Minniti (2009) who reported that in the developing countries, the majority of females who engaged in entrepreneurial activities are more driven than men by necessity to survive because there are no other options for income generation.

The results show further that in terms of business behaviour, more males $(81.3 \%)$ than females (33.3\%) easily take risk and also more males $(73.3 \%)$ than females $(53.3 \%)$ take advantage of business opportunities in tandem with Eckhardt and Shane (2003) who identified opportunity recognition as a major cause of gap between male and female entrepreneurs. On the other hand, more females $(48 \%)$ than males $(21.3 \%)$ easily satisfied with their business performance and more females (18.7\%) than males $(5.3 \%)$ fear business failure showing differences in business behaviour. The findings corroborate the arguments of Nelson (1989) and Ahl (2006) that gender gap in entrepreneurship is due to women's irrational behaviour, risk averseness and lack of necessary skills. Also more males $(68 \%)$ than females $(46.7 \%)$ had access to financial resources showing difference in access to credit. The finding agrees with Baughn et al., (2006) who described gender inequality in entrepreneurship as a function of lack of access to financial and social capital.

Table 3: Distribution of respondents by causes of entrepreneurship gap

\begin{tabular}{|c|c|c|}
\hline Variables & $\begin{array}{l}\text { Male }(n=75) \\
\text { Percentage }\end{array}$ & $\begin{array}{ll}\text { Female } & (n=75) \\
\text { Percentage } & \end{array}$ \\
\hline \multicolumn{3}{|c|}{$\begin{array}{l}\text { Motives (reasons for engaging in the } \\
\text { enterprise) }\end{array}$} \\
\hline Augment family income & 12.0 & 65.3 \\
\hline To become Self independence & 21.3 & 18.7 \\
\hline To avoid idleness & 13.3 & 34.7 \\
\hline To leave legacy for children & 9.3 & 2.7 \\
\hline To contribute to community development & 30.7 & 8.0 \\
\hline To reduce unemployment & 24.0 & 29.3 \\
\hline For profit making & 73.3 & 65.3 \\
\hline \multicolumn{3}{|l|}{ Behaviour } \\
\hline Not easily discourage & 34.7 & 26.7 \\
\hline Easily take risk in business & 81.3 & 33.3 \\
\hline Fear of business failure & 5.3 & 18.7 \\
\hline Easily satisfied with what I get & 21.3 & 48.0 \\
\hline Take advantage of business opportunity & 73.3 & 53.3 \\
\hline \multicolumn{3}{|l|}{ Accessibility to financial resources } \\
\hline Had access credit & 68.0 & 46.7 \\
\hline Had no access & 32.0 & 53.3 \\
\hline
\end{tabular}

Source: Field Survey, 2017 
Creative Commons User License: CC BY-NC-ND

Abstracted by: EBSCOhost, Electronic Journals Service (EJS)

Google Scholar, Journal Seek, Scientific Commons,

Food and Agricultural Organization (FAO), CABI and Scopus
Journal of Agricultural Extension

Vol. 23 (1) January, 2019

ISSN(e): 24086851; ISSN(Print); 1119944X

http://journal.aesonnigeria.org

http://www.ajol.info/index.php/jae

Email: editorinchief@aesonnigeria.org

\section{Perception of Respondents towards Entrepreneurship}

Table 4 shows that there was a difference in the perception grand mean score of males (3.22) and females (2.52) and that the perception statement that ranked highest among the male respondents was that, "male entrepreneurs are more cautious in decision making" (mean= 3.85) while among the female respondents, it was the statement that "female entrepreneurs are as competent as their male counterpart" (mean=4.28). The result concurs with Anna et al. (2000) who identified differences between men and women entrepreneurs with respect to perception and decision making style (Baker and Nelson, 2005).

Table 4: Distribution of respondents by their perception towards entrepreneurship

\begin{tabular}{|c|c|c|c|c|}
\hline \multirow[t]{2}{*}{ Perceptional statements } & \multicolumn{2}{|c|}{ Male $(n=75)$} & \multicolumn{2}{|c|}{ Female $(n=75)$} \\
\hline & Mean & Rank & Mean & Rank \\
\hline Male entrepreneur are more cautious in decision making & 3.85 & $1^{\text {st }}$ & 2.90 & $3^{\text {rd }}$ \\
\hline Entrepreneurial activities are male dominated in this area. & 3.60 & $2^{\text {nd }}$ & 2.57 & $5^{\text {th }}$ \\
\hline $\begin{array}{l}\text { Female child only have supportive roles to play in family } \\
\text { business }\end{array}$ & 3.53 & $3^{\text {rd }}$ & 2.60 & $4^{\text {th }}$ \\
\hline $\begin{array}{l}\text { Female entrepreneurs are as competent as their male } \\
\text { counterpart }\end{array}$ & 3.50 & $4^{\text {th }}$ & 4.28 & $1^{\text {st }}$ \\
\hline Female entrepreneurs are after profit more than male & 3.30 & $5^{\text {th }}$ & 3.82 & $2^{\text {nd }}$ \\
\hline $\begin{array}{l}\text { It is preferable to give male children entrepreneurial orientation } \\
\text { and training from childhood }\end{array}$ & 3.03 & $6^{\text {th }}$ & 2.31 & $7^{\text {th }}$ \\
\hline $\begin{array}{l}\text { Entrepreneurial activities managed by male are more successful } \\
\text { than those of female }\end{array}$ & 2.70 & $7^{\text {th }}$ & 2.36 & $6^{\text {th }}$ \\
\hline Female entrepreneurial activities are more prone to risk & 2.24 & $8^{\text {th }}$ & 2.24 & $8^{\text {th }}$ \\
\hline
\end{tabular}

Grand mean for male $=3.22$, grand mean for 2.52

Source: Field Survey, 2017

\section{Strategies of Bridging Entrepreneurship Gap Between Male and Female}

Results in Table 5 show that respondents identified multiple means of bridging the gap between male and female entrepreneurs. The majority $(93.3 \%$ and $96.0 \%)$ of male and female entrepreneurs identified accessibility to credit as the most important means of bridging the gap. In addition, most males identified provision of entrepreneurship education $(78.7 \%)$, provision of infrastructure $(76.0 \%)$ and provision of entrepreneurship opportunities (73.3\%) while most females identified provision of infrastructure $(86.7 \%)$, legislation of gender sensitive policy (81.3\%) and advocacy for gender mainstreaming in entrepreneurship (73.3\%). This shows that efforts to bridge entrepreneurship gap should marry the interest of both genders in addressing the issue. 
Creative Commons User License: CC BY-NC-ND

Journal of Agricultural Extension

Abstracted by: EBSCOhost, Electronic Journals Service (EJS), Vol. 23 (1) January, 2019

Google Scholar, Journal Seek, Scientific Commons,

Food and Agricultural Organization (FAO), CABI and Scopus

http://eoi.citefactor.org/10.11226/v23i1
ISSN(e): 24086851; ISSN(Print); 1119944X

http://journal.aesonnigeria.org

http://www.ajol.info/index.php/iae

Email: editorinchief@aesonnigeria.org

Table 5: Distribution of respondents by strategies of bridging gender gap

\begin{tabular}{lll}
\hline Means of bridging the gap & $\begin{array}{c}\text { Male }(\mathbf{n}=\mathbf{7 5}) \\
\text { Percentage }\end{array}$ & $\begin{array}{c}\text { Female(n=75) } \\
\text { percentage }\end{array}$ \\
\hline Legislation of gender sensitive policy & 68.0 & 81.3 \\
Provision of infrastructure & 76.0 & 86.7 \\
Provision of entrepreneurship education & 73.3 & 68.0 \\
Provision of entrepreneurship opportunities & 78.7 & 67.7 \\
Accessibility of credit facilities & 93.3 & 96.0 \\
Availability of labour & 48.0 & 50.7 \\
Preference to locally made goods and services & 68.0 & 68.0 \\
Availability of land & 53.3 & 65.3 \\
Provision of appreciable number of extension agents & 30.7 & 50.7 \\
Advocacy for gender mainstreaming in entrepreneurship & 32.0 & 73.3 \\
\hline Source: Fin
\end{tabular}

Source: Field Survey, 2017

\section{Differences in Male and Female Enterprise Characteristics}

Table 6 shows that there were significant differences between male and female entrepreneurs' enterprise characteristics such as income size ( $t=4.645 ; p \leq 0.01)$, operational coverage $(t=5.031 ; p \leq 0.01)$, business choice $(t=8.946 ; p \leq 0.01)$, staff strength $(t=4.944 ; p \leq 0.01)$ and initial capital investment $(t=4.646 ; p \leq 0.01)$ The implication of the finding is that income size, business choice, staff strength, initial capital investment and operational coverage were the significant enterprise characteristics in entrepreneurship development in the study area.

Table 5: Differences between male and female enterprise characteristics

\begin{tabular}{lccc}
\hline Enterprise characteristics & $\begin{array}{l}\text { Male } \\
\text { Mean }\end{array}$ & $\begin{array}{c}\text { Female } \\
\text { Mean }\end{array}$ & t- value \\
\hline Income size & 26326 & 14013 & $3.921^{\star \star}$ \\
Operational coverage & 3.000 & 1.053 & $5.031^{\star *}$ \\
Business choice & 5.466 & 3.665 & $8.946^{\star *}$ \\
Staff strength & 2.293 & 0.880 & $4.944^{\star \star}$ \\
Initial capital outlay & 97607 & 35698 & $4.646^{\star \star}$ \\
Exit rate & 0.213 & 0.320 & 0.421 \\
\hline
\end{tabular}

** $P \leq 0.01$

Source: Field Survey, 2017

\section{Differences in Male and Female Causes of Entrepreneurship Gap}

Results in Table 7 show that significant differences existed in causes of entrepreneurship gap among male and female entrepreneurs such as behaviour ( $t=-2.243 ; p \leq 0.05)$, accessibility to financial resources $(t=3.921 ; p \leq 0.01)$, motive $(t=-2.616 ; p \leq 0.01)$ and perception towards entrepreneurship $(t=2.918 ; p \leq 0.05)$. This implies that behaviour, accessibility to financial resources, motive and perception towards entrepreneurship were the significant causes of the entrepreneurship gap among male and female business owners in the study area. 
Creative Commons User License: CC BY-NC-ND

Abstracted by: EBSCOhost, Electronic Journals Service (EJS),

Google Scholar, Journal Seek, Scientific Commons,

Food and Agricultural Organization (FAO), CABI and Scopus

http://eoi.citefactor.org/10.11226/v23i1
Journal of Agricultural Extension

Vol. 23 (1) January, 2019

ISSN(e): 24086851; ISSN(Print); 1119944X

http://journal.aesonnigeria.org

http://www.ajol.info/index.php/iae

Email: editorinchief@aesonnigeria.org

Table 7: Differences between male and female causes of entrepreneurship Gap

\begin{tabular}{llcc}
\hline Causes of gap & $\begin{array}{l}\text { Male } \\
\text { Mean }\end{array}$ & $\begin{array}{c}\text { Female } \\
\text { Mean }\end{array}$ & t- value \\
\hline Behaviour & 1.586 & 1.800 & $-2.243^{*}$ \\
Accessibility to financial resources & 97602 & 35698 & $4.645^{* *}$ \\
Motive & 1.8400 & 2.240 & $-0.616^{* *}$ \\
Perception toward entrepreneurship & 25.72 & 23.09 & $2.918^{* *}$ \\
\hline
\end{tabular}

** $P \leq 0.01$

Source: Field Survey, 2017

\section{Conclusion and Recommendations}

Female entrepreneurs tend to have latent entrepreneurial potential that is not yet realized, as observed in the various forms of gap existing between them and their male counterparts. Policy makers can help to unlock this potential by providing opportunities for improved accessibility of women entrepreneurs at the grass root to financial resources and other enabling factors. At the same time, adequate extension education on rural entrepreneurship capability development that will focus on stimulating positively on women's entrepreneurship motives, intentions and perception is germane to bridging the gap.

\section{Reference}

Ahl, H. (2006). Why research on women entrepreneurs needs: New directions. Entrepreneurship Theory and Practice, Vol.30, pp.595-621.

Alabi, D. L., Famakinwa, M. and Ogunjimi, S. I. (2017). Gender analysis of problems and prospects of rural household-based enterprises in Osun State, Nigeria. Scientific Series Management, Economic Engineering and Rural Development, 17(1), pp. 3137.

Allen, E., Elam, A., Langowitz, N., Dean, M. (2008). Global Entrepreneurship Monitor, 2007; Report on Women and Entrepreneurship. Babson College: The Center for Women's Leadership at Babson College, Lawrence N. Field, Center for Entrepreneurship, Baruch. Google Scholar

Anna, A., Chandler, G., Jansen, E. and Mero, N. (2000). Women business owners in traditional and non-traditional industries, Journal of Business Venturing, 15(3), pp. 279-303.

Baker, T. and Nelson, R. (2005). Creating something from nothing: Resource construction through entrepreneurship Bricolage Administrative Science Quarterly, 50, pp. 32966.

Baughn, C.; Chua, B.; Neupert, K. (2006) The Normative Context for Women's Participation in Entrepreneurship: A multicountry study. Entrepreneurship Theory and Practice Volume 30, Issue 5, Pp.687-708.

Deepak, K., Abhishek, N. and Chirag, S. (2014). The Gender Gap in Entrepreneurship and How to Overcome It? AStudy of Women Entrepreneurship Promotion in Uttarakhand State. Global Journal of Finance and Management,6 (2), pp.157-164

Deji, O. F (2011). Gender Concepts and Theories. Gender and Rural Development. Berlin series on society, economy and politics in developing countries. Volume1Spektrum publishers. ISBN 978-3-643-90103-3 Pp 21 
Creative Commons User License: CC BY-NC-ND

Abstracted by: EBSCOhost, Electronic Journals Service (EJS) Google Scholar, Journal Seek, Scientific Commons,

Food and Agricultural Organization (FAO), CABI and Scopus

http://eoi.citefactor.org/10.11226/v23i1
Journal of Agricultural Extension

Vol. 23 (1) January, 2019

ISSN(e): 24086851; ISSN(Print); 1119944X

http://journal.aesonnigeria.org

http://www.ajol.info/index.php/iae

Email: editorinchief@aesonnigeria.org

Eckhardt, J. and Shane, S. (2003) Opportunities and Entrepreneurship. Journal of Management,Vol. 29 No. 3, p. 333-49.

Fielden, S. L., Davidson, M. J. \& Makin P. J. (2000). Barriers Encountered During Micro and Small Business Start-up in North-West England. Journal of Small Business and Enterprise Development, Vol. 7, No. 4. Pp. 295-304

Kelley, D.J., Brush, C.G., Greene, P.G. and Litovsky, Y. (2011). Global Entrepreneurship Monitor: 2010 Women's Report. Boston: The Center for Women's Leadership at Babson College and London Business School.Google Scholar

Minniti M. (2009). Gender Issues in Entrepreneurship. Foundations and Trends in Entrepreneurship, Vol. 5, Nos 7-8: p. 497 -621.

Naude, W. and Minniti, M. (2011). Examining the entrepreneur gender gap. Economic Development, Female entrepreneurs in developing countries. United Nations University.htm

Nelson, G. (1989) Factors of friendship: Relevance of Significant others to Female Business Owners. Entrepreneurship Theory and Practice, 13(4), 7-18.

Nitin,S., Avinash, S., Aditi, S., Vinay, S. and Roshan, S. (2011). Rural Entrepreneurship Final https://www.slideshare.net/dk2687/rural-entrepreneurship-final Pp. 1-25.

Revenga, A. and Sudhir, S. (2012). Empowering women is smart economics. Finance \& Development. 49(1):40-43

Robbins, S.P., \& Coulter, M. (1998). Management, India: Prentice Hall, 19.

Sameer, C. (2014). Rural Entrepreneurship in Detail Pp. 1-87. https://www.slideshare.net/sameer9189/rural-entrepreneurship-in-detail

Sarfaraz , L., Faghih, N. and Majd, A. A. (2014).The Relationship between Women Entrepreneneurship and Gender Equality. Journal of Global Entrepreneurship Research

Sarfaraz, L. and Faghih, N. (2011). Women's Entrepreneurship in Iran: a GEM based-data evidence. Journal of Global Entrepreneurship Research 1(1):45-57. Google Scholar

Trupti, M. (2010). Rural Entrepreneurship. Pp 1-22. Available at https://www.slideshare.net/truptimusale/rural-entrpreneurship

Tunde, A. M and Adeniyi, E. E. (2012). Impact of Road Transport on Agricultural Development: A Nigeria Example. Ethiopian Journal of Environmental Studies and Management 5(3), 232-238. http://dx.doi.org/10.4314/ejesm.v5i3.3

United Nations Population Fund (2013). Gender Equality: A Cornerstone of Development. retrieved in 2013 from http://www.unfpa.org/genderGoogle Scholar 